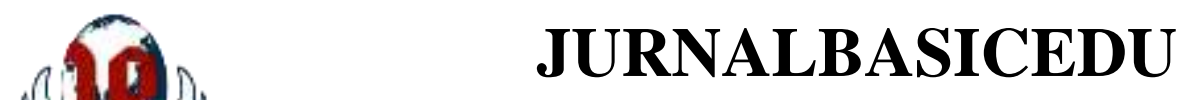

Volume 5 Nomor 5Tahun 2021 Halaman 3541 - 3550

Research \&Learningin Elementary Education https://jbasic.org/index.php/basicedu

\title{
Penerapan Model Value Clarifications Technique (VCT) pada Pembelajaran PKn di Sekolah Dasar
}

\author{
Ermawati $^{1 凶}$, Andriana Sofiarini ${ }^{2}$, Andri Valen ${ }^{3}$ \\ Pendidikan Guru Sekolah Dasar, STKIP-PGRI Lubuklinggau, Indonesia ${ }^{1,2,3}$ \\ E-mail: Ermawatii2004@gmail.com ${ }^{1}$, valen.andri87@ gmail.com ${ }^{3}$
}

\begin{abstract}
Abstrak
Penelitian ini bertujuan untuk mengetahui ketuntasan hasil belajar PKn setelah diterapkan Model Value Clarification Technique (VCT) pada pembelajaran PKn Siswa Kelas V SD Negeri 1 Sungai Pinang. Jenis penelitian yang digunakan adalah penelitian eksperimen. Populasi penelitian adalah seluruh siswa kelas V SD Negeri 1 Sungai Pinang tahun ajaran 2021/2022. Pemilihan sampel dilakukan dengan teknik sampling jenuh. Sampel yang diambil adalah 16 siswa dan diajarkan dengan model pembelajaran Value Clarification Technique (VCT). Metode penelitian menggunakan eksperimen semu. Teknik pengumpulan data menggunakan tes berbentuk soal esay. Data yang diperoleh dianalisis menggunakan uji-z. Berdasarkan hasil penelitian dan pembahasan diperoleh nilai rata-rata 71,56 dengan ketuntasan belajar 87,5\%. Hasil analisis uji$\mathrm{z}$ diperoleh $\mathrm{Z}_{\text {hitung }}=4,82>\mathrm{z}_{\text {tabel }}=1,64$ yang menunjukkan bahwa hipotesis $\mathrm{H}_{\mathrm{o}}$ ditolak dan $\mathrm{H}_{\mathrm{a}}$ diterima. Jadi dapat disimpulkan bahwa hasil belajar PKn siswa kelas V SD Negeri 1 Sungai Pinang setelah penerapan model Value Clarifications Technique (VCT)berada pada kategori signifikan tuntas.
\end{abstract}

Kata Kunci: Model Value Clarifications Technique (VCT), Hasil Belajar PKn, Sekolah Dasar.

\begin{abstract}
This study aims to determine the completeness of Civics learning outcomes after applying the Value Clarification Technique (VCT) model to Civics learning for fifth grade students of SD Negeri 1 Sungai Pinang. The type of research used is experimental research. The research population is all fifth grade students of SD Negeri 1 Sungai Pinang for the academic year 2021/2022. Sample selection was done by saturated sampling technique. The sample taken was 16 students and taught using the Value Clarification Technique (VCT) learning model. The research method used quasi-experimental. The data collection technique used a test in the form of essay questions. The data obtained were analyzed using the z-test. Based on the results of research and discussion obtained an average value of 71.56 with a learning completeness of $87.5 \%$. The results of the $z$-test analysis obtained $z_{\text {count }}=4.82>z_{\text {table }}=1.64$ which indicates that the hypothesis Ho is rejected and Ha is accepted. So it can be concluded that the Civics Learning Outcomes of fifth grade students of SD Negeri 1 Sungai Pinang after the application of the Value Clarifications Technique (VCT) model are in the complete significant category.
\end{abstract}

Keywords:Value Clarifications Technique (VCT) Model, Civics Learning Outcomes, Elementary School.

Copyright (c) 2021 Ermawati, Andriana Sofiarini, Andri Valen

$\triangle$ Corresponding author :

Email : Ermawatii2004@gmail.com

DOI : https://doi.org/10.31004/basicedu.v5i5.1372

ISSN 2580-3735 (Media Cetak)

ISSN 2580-1147 (Media Online)

Jurnal Basicedu Vol 5 No 5 Tahun 2021

p-ISSN 2580-3735 e-ISSN 2580-1147 
3542 Penerapan Model Value Clarifications Technique (VCT) pada Pembelajaran PKn di Sekolah DasarErmawati, Andriana Sofiarini, Andri Valen

DOI: https://doi.org/10.31004/basicedu.v5i5.1372

\section{PENDAHULUAN}

Pendidikan adalah usaha sadar dan terencana untuk mewujudkan suasana belajar dan proses pembelajaran agar peserta didik secara aktif mengembangkan potensi dirinya untuk memiliki kekuatan spiritual keagamaan, pengendalian diri, kepribadian, kecerdasan, akhlak mulia, serta keterampilan yang diperlukan dirinya, masyarakat, bangsa dan negara. Menurut (Hamalik, 2007) pendidikan merupakan bagian integral dalam pembangunan. Saat ini, pendidikan di Indonesia mengalami perubahan secara bertahap sesuai dengan tujuan pendidikan nasional. Perubahan tersebut terjadi karena adanya pembaharuan-pembaharuan dalam dunia pendidikan. Pembaharuan yang dilakukan menuntut agar pendidikan semakin mengoptimalkan fungsi darikomponen-komponen pendidikan. Jika komponenkomponen pendidikan dapat berfungsi dengan baik, maka pencapaian tujuan pendidikan nasional akan semakin optimal. Komponen-komponen pendidikan yang saling terkait secara terpadu untuk mencapai tujuan pendidikan nasional disebut sebagai sistem pendidikan nasional. Jika semua komponen pendidikan telah terpenuhi dan saling terkait sesuai dengan sistem pendidikan nasional, maka pencapaian tujuan pendidikan nasional akan semakin optimal. Pembelajaran yang efektif dan menyenangkan dapat diterapkan diberbagai mata pelajaran, misalnya pada mata pelajaran Pendidikan Kewarganegaraan (PKn). Menurut (Susanto, 2012) Pendidikan kewarganegaraan adalah mata pelajaran yang digunakan sebagai wahana untuk mengembangkan dan melestarikan nilai luhur moral yang berakar pada budaya bangsa Indonesia. Hakikat Pendidikan Kewarganegaraan (PKn) merupakan sarana untuk mengembangkan dan melestarikan nilai-nilai luhur yang berakar pada budaya bangsa Indonesia dalam bentuk perilaku yang tercermin dalam kehidupan sehari-hari. Perilaku yang dimaksud adalah perilaku yang sesuai dengan nilai-nilai pancasila. PKn menekankan pada pembelajaran sikap dan mental siswa. Jadi, pembelajaran PKn diharapkan akan membentuk siswa yang memiliki sikap dan mental yang kuat, sehingga dapat mengatasi semua permasalahan yang dihadapi. Nilai-nilai dalam PKn sudah diterapkan kepada siswa sebelum memasuki sekolah dasar, yaitu melalui pendidikan yang dilakukan oleh orang tua dan pengaruh lingkungan sekitar. Jadi, seharusnya nilai-nilai PKn tersebut sudah membekas pada diri siswa mulai dari rumah dengan menerapkan kebiasaan-kebiasaan hidup yang baik.

Belajar adalah proses aktif individu dalam membangun pengetahuan dan pencapaian tujuan. (Andri Valen, 2020) menjelaskan bahwa setiap kegiatan pembelajaran bertujuan untuk memperoleh hasil yang maksimal, kegiatan ini akan tercapai jika siswa sebagai subjek terlibat aktif secara fisik maupun emosinya dalam pembelajaran. Guru harus dapat menerapkan pembelajaran yang efektif di sekolah agar inti dari pembelajaran PKn dapat dimengerti dan benar-benar diterapkan oleh siswa dalam kehidupan sehari-hari. Peranan guru sangat besar pengaruhnya terhadap perubahan kemampuan berpikir siswa, guru memiliki tugas untuk merencanakan pembelajaran, melaksanakan kegiatan pembelajaran, serta melakukan penilaian terhadap proses dan hasil belajar siswa (Valen, 2020). Upaya yang dapat dilakukan guru agar pembelajaran PKn menjadi efektif dan menyenangkan bagi siswa yaitu dengan menerapkan suatu model pembelajaran yang bervariasi. Guru harus mampu membuat suasana belajar menjadi nyaman bagi siswa. Selain itu, sarana dan prasarana yang tersedia harus bisa dimanfaatkan secara optimal oleh guru dan siswa dalam proses pembelajaran. Guru juga harus menggunakan desain dan strategi pembelajaran serta media yang sesuai dengan materi pembelajaran dan karakteristik siswa agar pembelajaran di kelas dapat meningkatkan hasil belajar siswa. Hasil belajar adalah prestasi belajar yang dicapai siswa dalam proses kegiatan belajar mengajar dengan membawa suatu perubahan dan pembentukan tingkah laku seseorang.

Kenyataan yang terjadi di lapangan menunjukkan bahwa pembelajaran PKn yang dilakukan guru seringkali masih monoton. Guru hanya menggunakan metode ceramah dan tanya jawab dalam menyampaikan materi pembelajaran tanpa ada variasi dengan metode lain. Selain itu, guru juga belum 
3543 Penerapan Model Value Clarifications Technique (VCT) pada Pembelajaran PKn di Sekolah DasarErmawati, Andriana Sofiarini, Andri Valen

DOI: https://doi.org/10.31004/basicedu.v5i5.1372

menggunakan media dalam proses pembelajarannya. Akibatnya, siswa menjadi cepat jenuh dan sukar untuk memahami materi pembelajaran. Berdasarkan hasil observasi yang dilakukan penulis kepada ibu Manirah selaku wali kelas V sehingga diperoleh informasi bahwa jumlah siswa di kelas V adalah 16 siswa, dan hasil belajar PKn masih banyak dibawah KKM yaitu 60 dengan rata-rata nilai sebesar 48,56. Dengan kata lain, masih ada $62 \%$ siswa kelas $\mathrm{V}$ pada tahun ajaran tersebut yang memperoleh nilai mata pelajaran PKn dibawah KKM. Dalam proses pembelajaran PKn, guru belum menggunakan metode pembelajaran bervariasi yang dapat mengukur suatu nilai hasil belajar, masih banyak menggunakan metode ceramah dan penugasan. Menurut (Andri valen, 2021) upaya untuk meningkatkan mutu pendidikan dan prestasi belajar siswa telah banyak dilakukan, melalui perubahan kurikulum, strategi pembelajaran, model pembelajaran dan instrument penilaian. Namun perubahan tersebut ternyata belum dapat meningkatkan kemampuan berpikir, kompetensi dan prestasi belajar siswa secara signifikan. Untuk itu perlu diterapkannya suatu model pembelajaran yang inovatif yang dapat meningkatkan penguasaan konsep pendidikan yaitu model Value Clarifications Technique (VCT).

Menurut (Salahudin, 2015)model pembelajaran adalah suatu perencanaan atau suatu pola yang digunakan sebagai pedoman dalam merencanakan pembelajaran di kelas. Model pembelajaran merupakan suatu pola berisi sintaks yang dijadikan sebagai acuan sebelum melaksanakan proses pembelajaran. Penggunaan model pembelajaran akan membantu guru dan siswa dalam kelancaran proses pembe lajaran, serta memperoleh hasil belajar yang optimal. Menurut (Adisusilo, 2017) dalam proses pembelajaran sangat dipengaruhi oleh model pembelajaran yang digunakan guru di sekolah. Salah satu model yang digunakan dalam proses belajar dalam pembelajaran PKn (pendidikan kewarganegaraan) adalah model Value Clarification Technique sering disingkat dengan VCT adalah pendekatan nilai di mana perserta didik dilatih untuk menemukan, memilih, menganalisis, memutuskan, mengambil sikap sendiri nilai-nilai hidup yang ingin diperjuangkannya yang merupakan metode menanamkan nilai dengan cara sedemikian rupa sehingga peserta didik memperoleh kejelasan atau kemantapan nilai. Dengan begitu siswa dapat menanamkan nilai kebaikan dalam dirinya sehingga kekerasan terhadap pelajar dapat diminimalisir.

(Fhaturrohman.,Wuri, 2011) mengungkapkan bahwa VCT merupakan model menanamkan nilai (values) dengan cara sedemikian rupa sehingga peserta didik memperoleh kejelasan /kemantapan nilai. Dengan kalarifikasi nilai, peserta didik tidak diperintahkan menghafal dan tidak "disuapi"dengan nilai-nilai yang sudah ada dipilihkan pihak lain, melainkan mempertanggung jawabkan, mengembangkan, memilih mengambil sikap dan mengamalkan nilai-nilai hidupnya sendiri. (Sanjaya, 2008) mengemukakan bahwa klarifikasi nilai adalah proses memberikan bantuan kepada setiap anak untuk memahami dan menyadari (mengklarifikasi) untuk apa hidup serta mengklarifikasi bentuk-bentuk perilaku apa yang layak dikerjakan. Dalam metode ini anak didorong untuk mendefinisikan nilai diri mereka sendiri dan memahami mulai dari orang lain.

Berdasarkan pemaparan di atas, maka dapat diketahui bahwa VCT adalah suatu cara yang bertujuan untuk mencari, menentukan nilai dan menggambil nilai yang baik, melalui analisis nilai yang sudah ada dalam diri siswa hingga mendapatkan kejelasan atau kemantapan nilai dan dapat tertanam dalam dirisiswa. Hal ini selaras dengan pendapat (Haris \& Gunansyah, 2013) menjelaskan bahwa model VCT pembelajaran berbasis model VCT merupakan salah satu teknik pendidikan nilai dimana peserta didik dilatih untuk menemukan, memilih, menganalisis, membantu siswa dalam mencari dan memutuskan mengambil sikap sendiri mengenai nilai-nilai hidup yang ingin diperjuangkannya. Pada dasarnya bersifat induktif, berangkat dari pengalamanpengalaman kelompok menuju ide-ide yang umum tentang pengetahuan dan kesadaran diri. Kelebihan model VCT adalah membantu siswa mampu menanamkan nilai dan moral dalam diri mereka serta dapat mengklarifikasi dan mengungkapkan isi makna materi nilai yang disampaikan oleh guru, mengklarifikasi dan menilai kualitas moral dalam diri siswa dan nilai moral dalam kehidupan nyata. 
3544 Penerapan Model Value Clarifications Technique (VCT) pada Pembelajaran PKn di Sekolah DasarErmawati, Andriana Sofiarini, Andri Valen

DOI: https://doi.org/10.31004/basicedu.v5i5.1372

Siswa sekolah dasar merupakan anak yang paling banyak mengalami perubahan sangat drastis baik mental maupun fisik, semua sifat yang nyata dan muncul dalam suatu tindakan siswa dalam kehidupan seharihari. Siswa sudah dapat mengembangkan pikiran yang logis, sehingga dengan demikian sifat dan perbuatan manusia tidak akan lepas dari kodrat dan watak serta bentuknya yang berbeda-beda, maka tidak dipungkiri jika bentuk dan karakter siswa berbeda-beda. Berdasarkan permasalahan tersebut, maka peneliti tertarik untuk melakukan penelitian dengan judul "Penerapan Model Value Clarification Technique (VCT) pada pembelajaran PKn Sekolah Dasar". Tujuan penelitian ini adalah untuk mengetahui ketuntasan hasil belajar PKn setelah diterapkan Model Value Clarification Technique (VCT) pada Siswa Sekolah Dasar.

Penelitian (Nalar, Agustin., 2017) yang berjudul "Pengaruh Model Pembelajaran VCT Terhadap Penalaran Moral Siswa Dalam Pembelajaran PKn SD”. Hasil penelitian menunjukkan bahwa model pembelajaran VCT memberikan pengaruh positif terhadap kemampuan penalaran moral siswa, terdapat perbedaan yang signifikan pada kemampuan penalaran moral antara siswa yang memperoleh pembelajaran PKn menggunakan model VCT dengan siswa yang memperoleh pembelajaran PKn menggunakan model konvensional. Sedangkan penelitian (Eliana, Y. S \& Veronika, 2018) yang berjudul "Penerapan Model Pembelajaran Value Clarification Technique (VCT) Terhadap Hasil Belajar Afektif Pelajaran IPS". Hasil penelitian tersebut menunjukkan bahwa terdapat perbedaan hasil belajar ranah afektif siswa yang signifikan antara siswa yang mengikuti pembelajaran dengan model pembelajaran Value Clarification Technique (VCT) dan siswa yang mengikuti pembelajaran dengan model pembelajaran konvensional kelas V SD Negeri 03 Makong tahun pelajaran 2017/2018.

Persamaan yang terdapat dalam penelitian sebelumnya dengan penelitian yang dilakukan penulis yaitu dalam penggunaan Value Clarifications Technique (VCT) sebagai model pembelajaran. Kemudian persamaan lainnya adalah sama-sama melakukan penelitian di kelas V Sekolah Dasar sebagai subjek penelitian. Perbedaan penelitian ini terletak pada lokasi, tempat dan waktu penelitian. Selain itu metode penelitian dan materi yang digunakan penulis juga berbeda dengan penelitian sebelumnya. Penelitian penerapan model Value Clarifications Technique (VCT) pada pembelajaran PKn Sekolah Dasar belum pernah dilakukan oleh peneliti sebelumnya.

\section{METODE PENELITIAN}

Jenis penelitian yang digunakan pada penelitian ini adalah penelitian kuantitatif. Penelitian kuantitatif dapat diartikan sebagai metode penelitian yang berlandaskan pada filsafat positivisme, digunakan untuk meneliti pada populasi atau sampel tertentu, pengumpulan data menggunakan instrument penelitian, analisis data bersifat kuantitatif/statistik, dengan tujuan untuk menguji hipotesis yang telah ditetapkan. Metode penelitian yang digunakan dalam penelitian ini adalah metode eksperimen. Menurut (Sugiyono, 2016:107) metode penelitian eksprimen adalah metode penelitian yang digunakan untuk mencari perlakuan tertentu terhadap yang lain dalam kondisi yang terkendali. Jenis penelitian ini adalah penelitian Pre-Eksperimen Desain dengan desain eksperimen yang digunakan berbentuk desain one-group pre-test dan post-test. Dalam penelitian ini tidak menggunakan kelompok kontrol. Desain yang dilakukan dengan membandingkan hasil pre-test dan post-test. Adapun desain eksperimen pre-test dan post-test menurut (Sugiyono, 2016) desain dapat digambarkan sebagai berikut:

Tabel 1 Desain Eksperimen Pre-Test dan Post-Test Group

\begin{tabular}{ccc}
\hline Pre-test & Treatment & Post-test \\
\hline $\mathrm{O}_{1}$ & $\mathrm{X}$ & $\mathrm{O}_{2}$ \\
\hline
\end{tabular}

Sumber: (Sugiyono, 2016:111) 
3545 Penerapan Model Value Clarifications Technique (VCT) pada Pembelajaran PKn di Sekolah DasarErmawati, Andriana Sofiarini, Andri Valen

DOI: https://doi.org/10.31004/basicedu.v5i5.1372

Keterangan:

$\mathrm{O}_{1} \quad$ : Pre-test (sebelum diberi perlakuan)

$\mathrm{O}_{2} \quad$ : Post-test (setelah diberi perlakuan)

$\mathbf{X} \quad$ : Perlakuan (Treatment)

Penelitian ini dilaksanakan di SD Negeri 1 Sungai Pinang yang beralamatkan di jalan Lintas MuraMuba, Desa Sungai Pinang Kecamatan Muara Lakitan Kabupaten Musi Rawas Provinsi Sumatera Selatan. Penelitian ini dilaksanakan pada tanggal 27 Juli 2021 sampai dengan 27 Agustus 2021. Penelitian ini diawali dengan uji instrumen, pre-test,treatmen hingga post-test diakhiri dengan analisis data hipotesis dan penarikan kesimpulan.

Menurut Fraenkel dan Wallen dalam (Winarni, 2018)populasi adalah kelompok yang menarik peneliti, dimana kelompok tersebut oleh peneliti dijadikan sebagai objek untuk menggeneralisasikan hasil penelitian. Populasi adalah wilayah generalisasi yang terdiri atas: objek/subjek yang mempunyai kualitas dan karakteristik tertentu yang ditetapkan oleh peneliti untuk dipelajari dan kemudian ditarik kesimpulannya (Sugiyono, 2017). Berdasarkan dari beberapa pendapat tersebut dapat diambil batasan pengertian bahwa populasi adalah keseluruhan unsur objek yang diperlukan sebagai sumber data dengan karakteristik tertentu dalam sebuah penelitian yang kemudian ditarik sebuah kesimpulan. Adapun populasi dalam penelitian ini adalah seluruh siswa kelas V di SD Negeri 1 Sugai Pinang yang berjumlah 16 siswa yang terdiri dari 12 lakilaki dan 4 perempuan. Teknik penarikan sampel yang digunakan dalam penelitian ini adalah dilakukan dengan cara sampling jenuh. Sampling jenuh adalah teknik penentuan sampel bila semua anggota populasi digunakan sebagai sampel (Sugiyono, 2016:124). Hal ini karena di SD Negeri 1 Sungai Pinang hanya memiliki satu kelas pada tingkat kelas $\mathrm{V}$ maka yang menjadi sampel penelitian ini adalah seluruh siswa yang berjumlah 16 siswa. Untuk lebih jelas dapat dilihat pada tabel di bawah ini:

Tabel 2 Sampel Penelitian

\begin{tabular}{ccccc}
\hline \multirow{2}{*}{ No } & \multirow{2}{*}{ Kelas } & \multicolumn{2}{c}{ Jenis Kelamin } & \multirow{2}{*}{ Jumlah } \\
\cline { 3 - 4 } & & Laki-laki & Perempuan & \\
\hline 1. & $\mathrm{~V}$ & 12 & 4 & 16 \\
\hline
\end{tabular}

\section{Uji Validitas Instrumen}

Validitas adalah suatu ukuran yang menunjukkan tingkat-tingkat kevalidan atau kesahihan sesuatu instrumen. Suatu instrumen yang valid atau sahih mempunyai validitas tinggi. Sebaliknya, instrumen yang kurang valid berarti memiliki validitas rendah (Arikunto, 2010). Untuk menghitung koefisien validitas, digunakan rumus korelasi product moment. Reliabilitas soal merupakan suatu ukuran yang menyatakan tingkat kekonsistenan atau keajegan suatu soal tes (Jakni, 2016). Menurut (Arikunto, 2010) realibilitas artinya sesuatu instrumen cukup dapat dipercaya untuk digunakan sebagai alat pengumpulan data karena instrumen tersebut sudah baik. Instrumen yang sudah dapat dipercaya, yang reliabel akan menghasilkan data yang dapat dipercaya juga. Analisis reliabilitas tes pada penelitian ini diukur dengan menggunakan rumus Alpha $\left(r_{11}\right)$.

Menurut (Suryanto, 2016) daya beda adalah seberapa jauh butir soal tersebut dapat membedakan kemampuan individu peserta didik. Butir soal didukung potensi daya beda yang baik, akan mampu membedakan peserta didik yang memiliki kemampuan tinggi dengan peserta didik yang memiliki kemampuan rendah. Menurut (Suryanto, 2016) tingkat kesukaran merupakan salah satu karakteristik yang dapat menunjukkan kualitas butir soal tersebut apakah termasuk mudah, sedang, atau sukar.(Andri valen, 2021) menyatakan bahwa butir soal yang baik memiliki tingkatkan kesukaran sedang dalam artian tidak terlalu sukar dan tidak pula terlalu mudah. Soal yang terlalu mudah tidak merangsang siswa dalam memecahkan permasalahan, sebaliknya soal yang terlalu sukar akan menyebabkan siswa tidak mempunyai semangat dalam mengerjakan soal karena di luar jangkauan kemampuan siswa. 
Berdasarkan hasil uji coba instrumen, dari hasil uji validitas diketahui bahwa dari sepuluh soal tes esay, sembilan dinyatakan valid karena $r_{\text {hitung }}$ lebih besar dari $r_{\text {table. }}$. Sedangkan hasil uji coba reliabilitas diperoleh nilai $r_{11}$ sebesar 0,66 (Reliabilitas Tinggi). Kemudian hasil uji coba daya pembeda, terdapat empat soal yang memiliki daya pembeda cukup, lima soal memiliki daya pembeda jelek, satu soal yang memiliki daya pembeda sangat baik. Demikian juga hasil uji coba tingkat kesukaran bahwa dari sepuluh soal esay, terdapat tujuh soal yang memiliki tingkat kesukaran sedang dan tiga soal memiliki tingkat kesukaran mudah. Berdasarkan penjelasan hasil uji coba instrumen tersebut, maka dapat disimpulkan delapan soal dapat digunakan sebagai alat pengumpul data dan dua soal yang tidak valid tidak dapat digunakan. Hasil rekapitulasi uji coba instrumen dapat dilihat pada tabel. berikut.

Tabel 3 Hasil Rekapitulsi Uji Coba Instrumen

\begin{tabular}{|c|c|c|c|c|c|c|c|c|}
\hline \multirow{2}{*}{$\begin{array}{l}\text { No } \\
\text { Soal } \\
1\end{array}$} & \multicolumn{2}{|r|}{ Validitas } & \multirow[t]{2}{*}{ Reliabilitas } & \multicolumn{2}{|c|}{$\begin{array}{c}\text { Daya } \\
\text { Pembeda }\end{array}$} & \multicolumn{2}{|c|}{$\begin{array}{c}\text { Tingkat } \\
\text { Kesukaran }\end{array}$} & \multirow{2}{*}{$\begin{array}{l}\text { Keterangan } \\
\text { Digunakan } \\
\end{array}$} \\
\hline & 0,50 & Sedang & & 0,2 & Cukup & 0,88 & Mudah & \\
\hline 2 & 0,44 & Sedang & \multirow{9}{*}{$\begin{array}{c}0,66 \\
\text { (Tinggi) }\end{array}$} & 0,32 & Cukup & 0,78 & Mudah & Digunakan \\
\hline 3 & 0,51 & Sedang & & 0,18 & Jelek & 0,58 & Sedang & Digunakan \\
\hline 4 & 0,66 & Tinggi & & 0,16 & Jelek & 0,54 & Sedang & Digunakan \\
\hline 5 & 0,05 & Sangat Rendah & & 0 & Jelek & 0,62 & Sedang & Tidak Digunakan \\
\hline 6 & 0,52 & Sedang & & 0,14 & Jelek & 0,31 & Sedang & Digunakan \\
\hline 7 & 0,31 & Rendah & & 0,06 & Jelek & 0,91 & Mudah & Tidak Digunakan \\
\hline 8 & 0,76 & Tinggi & & 0,62 & Sangat Baik & 0,44 & Sedang & Digunakan \\
\hline 9 & 0,55 & Sedang & & 0,32 & Cukup & 0,69 & Sedang & Digunakan \\
\hline 10 & 0,48 & Sedang & & 0,25 & Cukup & 0,36 & Sedang & Digunakan \\
\hline
\end{tabular}

Teknik pengumpulan data yang digunakan dalam penelitian ini adalah teknik tes. Tes tersebut akan digunakan untuk mengumpulkan data berupa nilai tes siswa tentang hasil belajar siswa pada kelas V SD Negeri 1 Sungai Pinang. Tes adalah rangkaian pertanyaan atau alat lain yang digunakan untuk mengukur keterampilan, pengetahuan, intelegensi, kemampuan, atau bakat yang dimiliki oleh individu atau kelompok. Pada peneilitian ini tes diberikan dua kali, yaitu tes pertama diberikan sebelum proses pembelajaran (pre-test) dan tes kemampuan akhir (post-test), tes ini berbentuk esay dengan jumlah 8 soal.

\section{HASIL DAN PEMBAHASAN}

Penelitian ini dilaksanakan di SD Negeri 1 Sungai Pinang yang dimulai dari tanggal 27 Juli sampai dengan 27 Agustus 2021 dengan menggunakan satu sampel penelitian yaitu kelas V dengan jumlah siswa 16 orang. Pada penelitian ini proses pembelajaran menggunakan model VCT dengan materi yang digunakan pada pembelajaran PKn. Pelaksaan uji instrumenya dilakukan pada kelas VI (enam) atau kelas atas yang bertujuan untuk mengetahui valid atau tidaknya soal yang diuji pada kelas V (lima) yang akan diteliti. Setelah uji instrumen yang telah dilaksanakan dapat diketahui dari sepuluh soal esay hanya dua yang tidak valid dan delapan soal yang valid. Adapun pelaksanaan penelitian ini dilakukan sebanyak empat kali pertemuan yaitu dengan rincian satu kali tes kemampuan awal (pre-test), dua kali mengadakan pembelajaran dengan model VCT dan satu kali melakukan tes kemampuan akhir (post-test). Pemberian pre-test digunakan untuk mengetahui kemampuan awal siswa sebelum diberi perlakuan (treatment). Adapun data tes akhir (post-test) didapatkan setelah diterapkannya pembelajaran dengan menggunakan model VCT dalam pembelajaran PKn. Serta data tes akhir digunakan untuk mengetahui ketuntasan hasil belajar siswa setelah diterapkan pembelajaran dengan menggunakan model VCT. Analisis data yang digunakan untuk menjawab rumusan masalah atau menguji hipotesis yang telah di rumuskan. Kemampuan awal dan akhir siswa dapat dilihat pada tabel. berikut. 
3547 Penerapan Model Value Clarifications Technique (VCT) pada Pembelajaran PKn di Sekolah DasarErmawati, Andriana Sofiarini, Andri Valen

DOI: https://doi.org/10.31004/basicedu.v5i5.1372

Tabel 4 Nilai Rata-rata dan Simpangan Baku Pre-test dan Post-test

\begin{tabular}{ccc}
\hline Kelas & Rata-rata & Simpangan Baku \\
\hline Tes Awal (Pre-test) & 22 & 7,16 \\
\hline Tes Akhir (Post-test) & 71,56 & 9,60 \\
\hline
\end{tabular}

Berdasarkan tabel.4 diperoleh data bahwa seluruh siswa mendapat nilai kurang dari 60 atau tidak ada siswa yang tuntas 60 , dengan nilai rata-rata $(\bar{x})$ nilai secara keseluruhan sebesar 22, simpangan baku 7,16. Jadi secara deskripftif dapat dikatakan bahwa kemampuan awal siswa termasuk kategori belum tuntas. Hal ini dikarenakan siswa belum mengikuti kegiatan pembelajaran dengan model VCT. Berdasarkan tabel 4.2 dapat diketahui bahwa siswa yang mendapat nilai lebih dari atau sama dengan 60 atau yang tuntas yaitu ada 14 siswa $(87,50 \%)$ dengan rata-rata nilai hasil belajar siswa secara keseluruhan sebesar 71,56 dan simpangan baku 9,60. Nilai tertinggi hasil post-test yaitu 85 dan nilai terendahnya sebesar 59 dengan rentang nilai 26. Jadi secara deskriptif dapat dikatakan bahwa kemampuan akhir siswa setelah proses pembelajaran menggunakan model VCT termasuk kategori tuntas.

Hasil perhitungan data pre-test dan post-test menunjukkan bahwa antara nilai tes awal dan nilai tes akhir terdapat perubahan yang signifikan, ini dilihat dari peningkatan hasil rata-rata nilai tes awal 22 , kemudian menjadi 71,56 pada tes akhir yang artinya terdapat peningkatan sebesar 49,56 dan peningkatan persentase jumlah siswa yang tuntas yaitu sebesar $87,50 \%$. Dari hasil ini dapat diambil kesimpulan bahwa penerapan pembelajaran dengan menggunakan model VCT dapat meningkatkan hasil belajar PKn. Peningkatan rata-rata hasil belajar dapat dilihat pada grafik berikut.

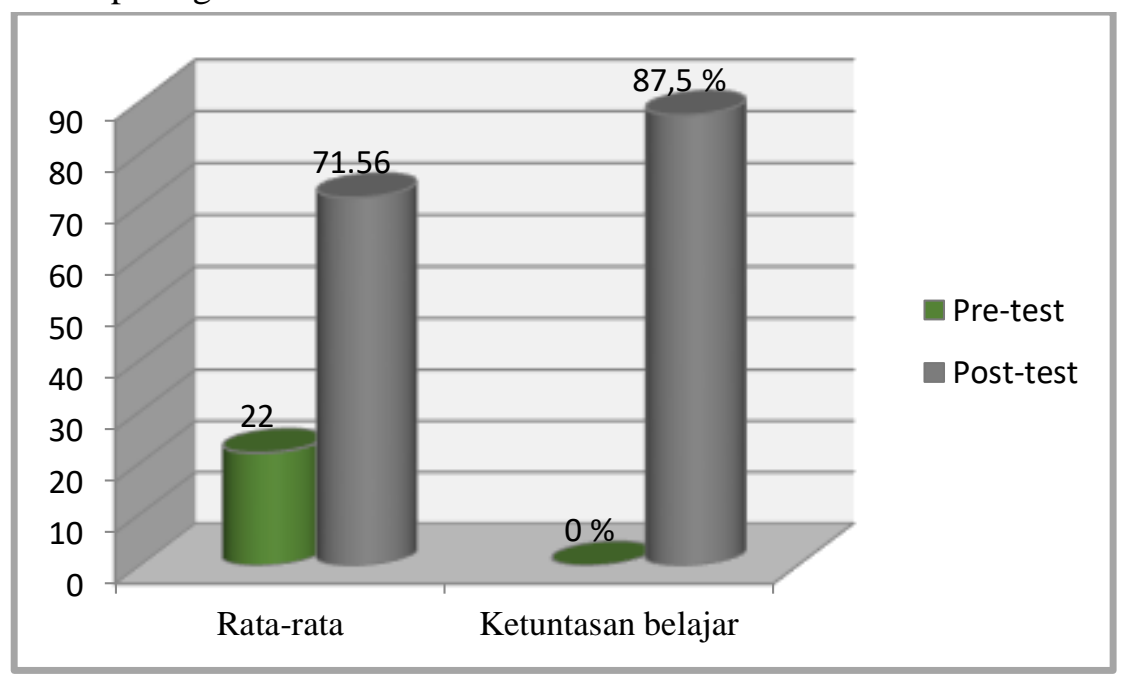

Nilai Rata-Rata Pre-test dan Post-test

\section{Pengujian Hipotesis}

\section{Uji Normalitas Data Pre-test dan Post-test}

Berdasarkan ketentuan perhitungan statistik mengenai uji normalitas data dengan taraf signifikan $\alpha=$

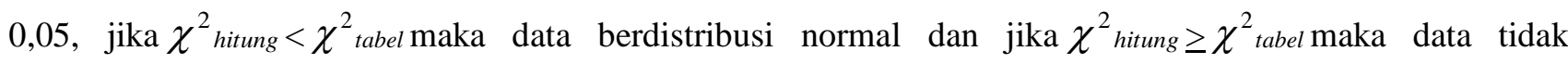
berdistribusi normal dengan nilai $\chi^{2}{ }_{\text {tabel }}$ ditentukan dengan $\mathrm{dk}=\mathrm{n}-1$. Uji normalitas dilakukan dengan tujuan untuk mengetahui apakah data hasil tes kemampuan siswa berdistribusi normal atau tidak. Untuk mengetahui kenormalan data, digunakan uji normalitas data dengan uji kecocokan $\chi^{2}$ (chi-kuadrat). Hasil perhitungan analisis data uji normalitas menunjukkan bahwa $\chi_{\text {hitung }}^{2}<\chi_{\text {tabel }}^{2}$, Dengan ketentuan untuk pengujian uji normalitas menggunakan uji $\chi^{2}$ (ChiKuadrat) dapat disimpulkan bahwa data tes awal (Pre-test) dan data tes akhir (Post-test) berdistribusi normal dengan taraf kepercayaan $\alpha=0,05$ dengan derajat kebebasan 
3548 Penerapan Model Value Clarifications Technique (VCT) pada Pembelajaran PKn di Sekolah DasarErmawati, Andriana Sofiarini, Andri Valen

DOI: https://doi.org/10.31004/basicedu.v5i5.1372

$(\mathrm{dk})=5$.Data hasil uji normalitas pre-test dan post-test dalam penelitian ini dapat dilihat pada tabel sebagai berikut:

Tabel 5 Hasil Uji Normalitas

\begin{tabular}{ccccc}
\hline Data & $\chi^{2}{ }_{\text {hitung }}$ & Dk & $\chi_{\text {tabel }}^{2}$ & Keterangan \\
\hline Pre-test & 5,9191 & 5 & 11,07 & Data Normal \\
\hline Post-test & 9,2161 & 5 & 11,07 & Data Normal \\
\hline
\end{tabular}

\section{UJI HIPOTESIS}

Berdasarkan hasil analisis data uji hipotesis diketahui data hasil post-test berdistribusi normal dan simpangan baku diketahui, maka dalam hal ini dilanjutkan dengan uji z. Data hasil perhitungan uji hipotesis pada data post-test dapat dilihat pada tabel. berikut.

Tabel 6 Hasil Uji Hipotesis

\begin{tabular}{cccc}
\hline Zhitung & Dk & $Z_{\text {tabel }}$ & Kesimpulan \\
\hline 4,82 & 15 & 1,64 & $\begin{array}{c}\text { Z hitung }_{\text {ta }} \geq \mathrm{Z}_{\text {tabel }}, \text { maka } \\
\mathrm{H}_{\mathrm{o}} \text { tolak dan } \mathrm{H}_{\mathrm{a}} \text { diterima }\end{array}$ \\
\hline
\end{tabular}

Hasil analisis uji-z mengenai kemampuan akhir siswa ini menunjukkan bahwa nilai Zhitung dibandingkan dengan $\mathrm{z}_{\text {tabel }} \mathrm{d}$ an $\alpha=0,05$ maka diperoleh $\mathrm{z}_{\text {hitung }}=4,82$, sedangkan $\mathrm{z}_{\text {tabel }}=1,64$. Dengan demikian $\mathrm{z}_{\text {hitung }}>\mathrm{z}_{\text {tabel }}$ hal ini dapat dikatakan bahwa $\mathrm{H}_{2}$ diterima dan $\mathrm{H}_{\mathrm{o}}$ ditolak, hipotesis yang diajukan pada penelitian ini dapat diterima kebenarannya. Sehingga dapat disimpulkan bahwa hasil belajar Pkn siswa kelas V SD Negeri 1 Sungai Pinang setelah diterapkan model VCTsecara signifikan tuntas.

Berdasarkan analisis secara statistik mengenai kemampuan akhir siswa menunjukkan bahwa hasil belajar PKn siswa kelas V SD Negeri 1 Sungai Pinang sudah tuntas pada taraf kepercayaan $\alpha=0,05$ Zhitung $(4,82)>z_{\text {tabel }}(1,64)$ terbukti bahwa pembelajaran PKn dengan menggunakan model VCTdapat meningkatkan hasil belajar siswa. Dengan demikian hipotesis penelitian yang diajukan dalam penelitian ini dapat diterima kebenarannya, maka dapat disimpulkan bahwa rata-rata hasil belajar siswa kelas V SD Negeri 1 Sungai Pinang tahun pelajaran 2020-2021 setelah mengikuti pembelajaran PKn menggunakan model VCT lebih besar atau sama dengan $60(\mu \geq 60)$. Adapun hasil penelitian dengan menggunakan model yang sama yaitu penelitian dari (Sri, 2017) yang berjudul "Penerapan Model VCT Permainan Untuk Meningkatkan Hasil Belajar Pendidikan Kewarganegaraan" mengalami peningkatan hasil belajar PKn dengan menggunakan model Value Clarification Technique dalam kategori baik. Hal ini dapat dilihat dengan persentase ketuntasan belajar sebesar $90,32 \%$, sedangkan nilai rata-rata sebesar 92,50.

Hasil belajar signfikan tuntas karena model VCT dapat, a) mengukur dan mengetahui tingkat kesadaran siswa tentang suatu nilai. b) menanamkan kesadaran siswa tentang nilai-nilai yang dimiliki siswa dengan tingkat sifat yang positif maupun sifat yang negatif dan selanjutnya ditanamkan ke arah peningkatan tentang nilai. c) menanamkan nilai-nilai tertentu yang diterima oleh siswa sehingga pada akhirnya nilai tersebut akan menjadi milik siswa sebagai proses kesadaran moral. d) melatih siswa dalam menerima nilai dirinya dan posisi nilai orang lain, menerima dan mengambil keputusan terhadap sesuatu persoalan yang berhubungan dengan pergaulannya dan kehidupan sehari-hari, Taniredja(Haris, 2013).

Selama proses pembelajaran dengan menggunakan model VCT, siswa-siswa terlibat secara aktif dalam proses pembelajaran. Hal ini dikarenakan siswa terlibat aktif dalam proses pembelajaran dan dapat melakukan interaksi dengan temannya serta saling menghormati dan menghargai pendapat orang lain. Dalam proses pembelajaran menggunakan model VCT siswa dapat belajar tanpa tekanan dan merasa gembira. Hal tersebut dikuatkan dengan penelitian sebelumnya oleh (Eliana, Y. S \& Veronika, 2018) menyatakan bahwa pembelajaran dengan model VCT mendapat respon yang positif dari siswa, hal itu menunjukan bahwa siswa menyukai pembelajaran dengan menggunakan VCT. 
3549 Penerapan Model Value Clarifications Technique (VCT) pada Pembelajaran PKn di Sekolah DasarErmawati, Andriana Sofiarini, Andri Valen

DOI: https://doi.org/10.31004/basicedu.v5i5.1372

Hasil penelitian ini menunjukkan bahwa hasil belajar PKn siswa meningkat tetapi dalam pelaksanaannya model VCT masih terdapat kendala yaitu beberapa siswa masih ada yang merasa kesulitan dan kurang aktif dan tidak mau bergabung bersama temannya. Walaupun ada kendala namun hal ini tidak menyurutkan konsentrasi siswa dalam belajar. Hal ini dapat dilihat dari pemberian treatment model VCT pada siswa pada pertemuan pertama masih banyak siswa yang masih bingung dalam penyelesaian masalah atau pengerjaan tugas dengan menggunakan model VCT namun secara perlahan guru memberikan perlakuan dan meyakinkan siswa sehingga pemberian tugas perlahan berjalan dengan baik.

\section{KESIMPULAN}

Penelitian ini menunjukkan pembelajaran dengan menggunakan model VCT siswa-siswa terlibat secara aktif dalam proses pembelajaran dan dapat melakukan interaksi dengan temannya serta saling menghormati dan menghargai pendapat orang lain. Dalam proses pembelajaran menggunakan model VCT siswa dapat belajar tanpa tekanan dan merasa gembira. Berdasarkan hasil penelitian dan analisis yang telah dilakukan di kelas V SD Negeri 1 Sungai Pinang maka dapat disimpulkan bahwa hasil belajar PKn siswa sekolah dasar setelah penerapan model Value Clarification Technique (VCT) secara signifikan tuntas. Oleh karena itu, pembelajaran dengan menggunakan model VCT dapat digunakan untuk menunjang proses pembelajaran serta dapat membantu guru dan siswa dalam meningkatkan hasil belajar, khususnya pembelajaran PKn di sekolah dasar.

\section{UCAPAN TERIMA KASIH}

Penelitian ini penulis banyak mendapat bantuan dari berbagai pihak. Oleh karena itu, penulis mengucapkan terima kasih kepada semua yang telah membantu penulisan skripsi ini. Secara khusus penulis mengucapkan terima kasih kepada:

1. Ibu Andriana Sofiarini, SH., M.Pd., dan Bapak Andri Valen, M.Pd yang telah bersedia memberikan bimbingan, arahan, dan memberikan pengetahuan tentang penelitian ini.

2. Bapak dan ibu Kepala Sekolah, Guru dan Staff SD Negeri 1 Sungai Pinang yang telah memberikan izin dan bantuan dalam penelitian ini.

3. Seluruh pihak yang selalu senantiasa memberikan memotivasi dan semangat pada penulis.

\section{DAFTAR PUSTAKA}

Adisusilo, S. (2017). Pembelajaran Nilai Karakte: Konstruktivisme Dan Vct Sebagai Inovasi Pendekatan Pembelajaran.

Andri Valen, A. S. E. (2020). Peningkatan Hasil Belajar Ips Melalui Model Student Team Achievement Division Siswa Kelas Iv Sd Negeri 82 Bengkulu. Inventa, 4(2), 181-189.

Andri Valen, T. G. S. (2021). Analisis Tingkat Kesukaran Soal Pas (Penilaian Akhir Semester) Mata Pelajaran Ips Di Sekolah Dasar. Basicedu, 5(4), 2199-2208.

Arikunto. (2010). Prosedur Penelitian.

Eliana, Y. S \& Veronika, C. (2018). Penerapan Model Pembelajaran Value Clarification Technique (Vct) Terhadap Hasil Belajar Afektif Pelajaran Ips. Pekan, 3(1), 11-16.

Fhaturrohman., W. (2011). Belajar Dan Pembelajaran Modern.

Hamalik, O. (2007). Kurikulum Dan Pembelajaran. 
3550 Penerapan Model Value Clarifications Technique (VCT) pada Pembelajaran PKn di Sekolah DasarErmawati, Andriana Sofiarini, Andri Valen

DOI: https://doi.org/10.31004/basicedu.v5i5.1372

Haris, F. (2013). Enerapan Model Pembelajaran Vct Untuk Meningkatkan Kesadaran Nilai Menghargai Jasa Pahlawan Pada Siswa Sekolah Dasar Negeri Semambung No. 296 Sidoarjo. E-Jurnal Unesa Jurnal Penelitian Pgsd, 1(2), 6-12.

Haris, F., \& Gunansyah, G. (N.D.). Penerapan Model Pembelajaran Vct (Value Clarification Technique ). 5.

Jakni. (2016). Metodologi Penelitian Eksperimen Bidang Pendidikan.

Nalar, Agustin., S. I. . (2017). Pengaruh Model Pembelajaran Vct Terhadap Penalaran Moral Siswa Dalam Pembelajaran Pkn Sd. Jurnal Moral Kemasyarakatan, 2(1), 59-74.

Salahudin. (2015). Penelitian Tindakan Kelas.

Sanjaya, W. (2008). Strategi Pembelajaran Berorientasi Standar Proses Pendidikan.

Sri, S. (2017). Penerapan Model Pembelajaran Value Clarification Technique Permainan Untuk Meningkatkan Hasil Belajar Pendidikan Kewarganegaraan. Jurnal Pendidikan Ilmu-Ilmu Sosial, 9(2), $255-262$.

Sugiyono. (2016). Metode Penelitian Pendidikan: Pendekatan Kuantitatif, Kualitatif, Dan R\&D.

Sugiyono. (2017). Metode Penelitian Kuantitatif, Kualitatif, Dan R\&D.

Suryanto. (2016). Evaluasi Pembelajaran Di Sd.

Susanto. (2012). Teori Belajar Dan Pembelajaran Di Sekolah Dasar.

Valen, A. (2020). Analisis Pemahaman Dan Kemampuan Guru Menyusun Soal Mid Semester Mata Pelajaran Ips Sekolah Dasar. Basicedu, 4(4), 1084-1097.

Winarni, E. . (2018). Teori Dan Praktik Penelitian Kuantitatif, Kualitatif, Ptk, R\&D. 